\title{
Hubungan Pengetahuan, Sikap, dan Dukungan Keluarga Terhadap Perilaku Terjadinya Resiko Kehamilan Usia Dini
}

\author{
Rita Haryani ${ }^{1}$, Ernita Prima ${ }^{2}$ \\ 1,2Program Studi Kesehatan Masyarakat \\ Sekolah Tinggi Imu Kesehatan Indonesia Maju \\ Gedung HZ Jl. Harapan No.50 Lenteng Agung Jakarta Selatan 12610 \\ Telp. (021) 788940444/45 Fax. (021) 78894045 \\ Email: ritamotyqu@gmail.com
}

\begin{abstract}
Abstrak
Hamil di usia dini merupakan masalah yang tidak asing lagi di dunia pendidikan akhir-akhir ini. Data dari hasil survei yang dilakukan oleh BKKBN 2010 sekitar 5I \% remaja di wilayah Jabodetabek sudah tidak perawan. Sebanyak 4\% responden yang mengaku melakukan hubungan seksual sejak usia 16-18 tahun, $16 \%$ melakukan pada usia I3-15 tahun. Penelitian ini bertujuan untuk mengetahui hubungan pengetahuan, sikap, dan dukungan keluarga terhadap perilaku terjadinya resiko kehamilan usia dini di SMP Negri 3 Gunung Putri Bogor. Penelitian ini dilakukan pada bulan oktober 20I4. Penelitian ini menggunakan metode cross sectional dimana data yang digunakan merupakan data primer yaitu dengan cara mengisi kuesioner. Penelitian ini menggunakan Random Sampling dimana Populasi berjumlah 160 responden dan sampel yang diambil sebanyak II 4 remaja putri di SMP Negeri 3 Gunung Putri Bogor. Hasil analisa dari II 4 responden menjelaskan bahwa responden yang tidak melakukan pencegahan kehamilan diusia dini sebanyak 67 orang (58,8\%), dengan pengetahuan rendah sebanyak 73 orang (64,0\%), sikap negatif sebanyak 60 orang (52,6\%), dan responden dengan dukungan keluarga yang tidak ada dukungan dari keluarga sebanyak 69 orang (60,5\%). Hasil analisis menggunakan Chi-Square dengan tingkat kemaknaan $\alpha=0,05$ menunjukan bahwa ada hubungan antara perilaku pencegahan kehamilan di usia dini dengan pengetahuan, sikap dan dukungan keluarga. Dari hasil penelitian ini disarankan bagi institusi pendidikan khususnya sekolah dalam menentukan program-program yang dapat menyebarluaskan informasi tentang pengetahuan pencegahan kehamilan di usia dini sehingga remaja terhindar dari dampak yang diakibatkan kehamilan di usia dini tersebut.
\end{abstract}

Kata kunci : Kehamilan usia dini, Pencegahan, Perilaku

\begin{abstract}
Pregnant at an early age is a problem that is no stranger to the world of education these days. Data from a survey conducted by BKKBN 2010, about $51 \%$ of adults in the Greater Jakarta area was not a virgin. As many as $4 \%$ of respondents who admitted having sexual intercourse since the age of 16-18 years, I6\% perform at the age of I3-15 years. This study aimed to determine the relationship of knowledge, attitudes, and family support to conduct the risk of teen pregnancy in SMP Negeri 3 Gunung Putri, Bogor. This research was conducted in October 2014. This study used a crosssectional method where data used is primary data that is by filling out a questionnaire. This study used a random sampling where the population numbered 160 respondents and I I 4 samples taken in the junior girls Negri 3 Gunung Putri, Bogor. Results of analysis of I 4 respondents explained that respondents who did early age pregnancy prevention as much as 67 people (58.8\%), with low knowledge of as many as 73 people (64.0\%), negative attitudes were 60 (52.6\%), and respondents with no family support of family support as many as 69 people (60.5\%). The results of the analysis using ChiSquare with significance level $\alpha=0.05$ indicates that there is a relationship between pregnancy prevention behaviors at an early age with the knowledge, attitude and family support. From the results of this study suggest that the educational institutions, especially schools in determining the programs that can disseminate information about pregnancy prevention knowledge at an early age so that teens avoid the impact of a pregnancy at such an early age.

Keywords : pregnancy at an early age, prevention, behavior.
\end{abstract}




\section{PENDAHULUAN}

Fenomena sosial yang merebak di kalangan remaja saat ini adalah hamil terlebih dulu baru menikah. Fenomena remaja cenderung menikah di usia dini karena ratarata mereka memiliki anak saat usia 15-19 tahun. ${ }^{1}$

Remaja yang sedang mencari identitas diri sangat mudah menerima informasi dunia berkaitan dengan masalah fungsi alat reproduksinya, sehingga cenderung menjurus ke arah pelaksanaan hubungan seksual yang semakin bebas. Remaja mulai mengenal cinta yang mereka wujudkan dalam sebuah hubungan berbalut kasih sayang dan rasa memiliki. Suatu proses yang menggambarkan pola ketertarikan antar individu yang melibatkan segenap emosional, jiwa dan raga yang disebut dengan istilah pacaran. Pacaran merupakan sebuah sarana untuk memenuhi tugas perkembangan sebagai remaja dalam hal mengembangan hubungan heteroseksual. Melalui pacaran dapat berkembang hubungan yang serius antar jenis kelamin. ${ }^{2}$

Hamil di usia dini merupakan masalah yang tidak asing lagi di dunia pendidikan akhir-akhir ini. Tidak sedikit siswi SMA dan SMP bahkan SD yang belum lulus dan belum menikah namun sudah hamil. Hal ini sungguh sangat disayangkan, usia yang tergolong masih sangat muda di mana seharusnya masih belajar di sekolah serta bermain bersama teman-temannya malah harus dipusingkan dengan masalah yang begitu berat. Masa remaja yang merupakan masa perkembangan dan seharusnya mereka gunakan untuk menuntut ilmu dan mempelajari banyak hal malah mereka hancurkan sendiri dengan melakukan hal-hal yang merugikan masa depan mereka sendiri. ${ }^{3}$

Sebuah survey yang dilakukan oleh Youth Risk Behavior Survei (YRBS) secara Nasional di Amerika Serikat pada tahun 2006 mendapati bahwa $47,8 \%$ pelajar yang duduk di kelas 9-12 telah melakukan hubungan seks pranikah, 35\% pelajar SMA telah aktif secara seksual. ${ }^{4}$ Perilaku remaja Indonesia sudah sangat mengkhawatirkan. Berbagai survei yang diadakan di kota- kota Indonesia menemukan Jumlah remaja yang sudah melakukan hubungan seks pra nikah mengalami peningkatan dari tahun ke tahun. Survei yang diadakan oleh Komnas PA (Perlindungan Anak) bekerja sama dengan Lembaga Perlindungan Anak di 12 kota besar pada tahun 2012 mendapatkan $62,7 \%$ remaja SMP mengaku sudah tidak perawan. Data BKKBN juga menunjukkan setiap tahun sedikitnya terjadi 2,4 juta kasus aborsi, termasuk 800.000 kasus yang dilakukan kalangan remaja. ${ }^{1}$ Hasil survey BKKBN 2010 sekitar $51 \%$ remaja di wilayah Jabodetabek sudah tidak perawan. Sebanyak $4 \%$ responden yang mengaku melakukan hubungan seksual sejak usia 16-18 tahun, $16 \%$ melakukan pada usia 13-15 tahun. Kejadian seks pranikah di Surabaya mencapai $47 \%$, di Bandung dan Medan 52\%. Perilaku seks bebas di kalangan remaja berdampak pada kasus infeksi penularan HIV/AIDS yang cenderung berkembang di Indonesia, sedangkan tempat favorit untuk melakukan hubungan seksual adalah di rumah sebanyak $40 \%$, di tempat kost $30 \%$ dan di hotel 30\%. ${ }^{4}$ Departemen Kesehatan Republik Indonesia (2010/2011) mengungkapkan bahwa dari 1189 remaja melakukan hubungan intim belum menikah (berusia 13-19 tahun) di Jawa Barat dan 922 remaja di Bali, ditemukan $7 \%$ remaja perempuan di Jawa Barat dan 5\% di Bali mengakui pernah mengalami kehamilan. Ketua Jaringan Peduli Perempuan dan Anak (JPPA) Jawa Tengah, jumlah siswi yang hamil akan terus meningkat, tercermin dari penelitiannya pada sekolah jenjang SMP dan SMA tahun 2010 yang menunjukkan dalam tiap sekolah rata-rata ditemukan empat hingga tujuh siswa yang hamil, bahkan pada tahun tersebut kenaikannya $10 \%$ hingga $15 \%$. Dari penelitian sebelumnya yang di teliti oleh Sekarrini tahun 2011 terhadap murid SMK Kesehatan di Kabupaten Bogor diketahui bahwa $60,7 \%$ responden berperilaku seksual berisiko berat seperti melakukan mencium bibir, mencium leher, meraba daerah erogen, bersentuhan alat kelamin dan melakukan hubungan seks. Sedangkan 39,3\% berperilaku seksual dalam kategori ringan seperti mengobrol, menonton film berdua, jalan 
berdua, berpegangan tangan, mencium pipi dan berpelukan. ${ }^{5}$

Dari hasil studi pendahuluan yang di lakukan oleh peneliti dengan 10 orang siswi di SMP Negeri 3 Gunung Putri Kabupaten Bogor didapatkan bahwa ada 6 orang yang mengaku pernah berciuman bibir dengan pacarnya, 2 orang mengaku pernah berpelukan dengan pacarnya, dan 2 orang mengaku tidak pernah melakukan apa-apa dengan pacarnya. Dan dari informasi yang didapat peneliti dari informan terpercaya yaitu guru BK dan wakil kepala sekolah bahwa pernah terdapat siswi yang hamil diluar nikah, dan informasi terbaru awal tahun 2014 terdapat siswi kelas III yang hamil di luar nikah.

Perilaku seksual remaja merupakan salah satu faktor pencetus kehamilan usia muda. Perilaku ingin mencoba hal yang baru jika didorong oleh rangsangan seksual yang salah dapat membawa remaja berperilaku seksual yaitu berfantasi, masturbasi, cium pipi, cium bibir, petting, dan berhubungan intim (intercourse). ${ }^{6}$

Beberapa ahli berpendapat bahwa penyimpangan perilaku seksual remaja yang mengarah pada kehamilan usia muda dapat dicegah. Beberapa perilaku pencegahan yang dapat dilakukan antara lain meningkatkan partisipasi diri dalam pengembangan aktivitas pendidikan sebaya, meminimalkan keingintahuan akan informasi tentang seks yang bersumber dari media massa dan hiburan, serta lebih mendekatkan diri dalam lingkungan keluarga. ${ }^{7}$

Masalah kehamilan remaja banyak sekali kita temui karena Program Pendidikan Kesehatan Reproduksi Remaja dan Pendidikan Seks di sekolah masih sangat kurang dan bahkan tidak ada. Padahal pendidikan seks pada remaja berperan besar dikalangan remaja. Tanpa adanya pengetahuan yang cukup bagi remaja, maka remaja dapat terjerumus ke hal-hal yang tidak semestinya seperti seks bebas yang dapat mengakibatkan kehamilan pada remaja/kehamilan pada usia dini. Berbicara tentang pendidikan seks dan kesehatan reproduksi tentunya tidak terlepas dengan pemahaman seseorang terhadap apa dan bagaimana pendidikan seks itu sendiri. Perbedaan pemahan tentang pendidikan seks dan kesehatan reproduksi ini tergantung pada bagaimana sudut pandang yang mereka gunakan dalam memberikan definisi tersebut. ${ }^{8}$

Terkait dengan masalah yang di paparkan tersebut, peneliti berpendapat bahwa semakin remaja tidak mengetahui dampak atau resiko dari kehamilan diusia dini atau pengetahuan, sikap dan dukungan keluarga yang baik mengenai kesehatan reproduksi dan pendidikan seks maka akan semakin meninggkat pula remaja melakukan seks bebas yang mengarah pada kehamilan diusia dini.

Sampai saat ini angka kejadian kehamilan pada remaja/kehamilan di usia dini masih tinggi. Peneliti berharap agar angka kejadian kehamilan di usia dini menurun sehingga tidak ada lagi remaja putri yang putus sekolah, dikucilkan, bahkan tidak ada lagi kasus aborsi yang banyak dilakukan dikalangan remaja, dengan ini maka peneliti tertarik untuk meneliti tentang bagaimana "Hubungan Pengetahuan, Sikap dan Dukungan Keluarga Terhadap Perilaku Pencegahan Resiko Kehamilan di Usia Dini Pada Remaja Putri di SMP Negeri 3 Gunung Putri Kabupaten Bogor Tahun 2014”. Subjek yang dipilih adalah remaja putri karena kesehatan reproduksi wanita khususnya remaja sangat penting untuk dapat menghasilkan generasi penerus yang baik.

Tujuan umum dari penelitian ini yaitu untuk mengetahui hubungan pengetahuan, sikap, dan dukungan keluarga terhadap perilaku pencegahan resiko kehamilan usia dini di SMP Negri 3 Gunung Putri Bogor tahun 2014.

\section{METODE}

Penelitian ini menggunakan metode kuantitatif, dengan menggunakan desain cross sectional dimana data yang digunakan merupakan data primer yaitu dengan cara mengisi kuesioner terhadap hubungan pengetahuan, sikap dan dukungan keluarga remaja putri terhadap perilaku pencegahan resiko kehamilan usia dini. Populasi adalah seluruh siswi kelas III di SMP Negeri 03 
Gunung Putri Bogor bulan Oktober tahun 2014 yang berjumlah 160 siswi. Teknik pengambilan sampel pada penelitian ini adalah dengan menggunakan metode Random Sampling, yaitu cara pemilihan sampel dimana anggota dari populasi dipilih satu persatu secara random atau acak, jumlah sampel yang didapat 114 siswi kelas III di SMP Negeri 3 Gunung Putri Kabupaten Bogor tahun 2014. Analisis data menggunakan analisis univariat dan analisis bivariat.

\section{HASIL}

Tabel 1. Gambaran Karakteristik Responden Berdasarkan Variabel yang Diteliti

\begin{tabular}{llcc}
\hline \multicolumn{1}{c}{ Variabel } & \multicolumn{1}{c}{ Kategori } & n & \% \\
\hline \multirow{3}{*}{ Perilaku } & Tidak & & \\
& melakukan & 67 & $58,8 \%$ \\
\multirow{2}{*}{ Pengetahuan } & Melakukan & 47 & $41,2 \%$ \\
\multirow{2}{*}{ Sikap } & Rendah & 73 & $64,0 \%$ \\
& Tinggi & 41 & $36,0 \%$ \\
Dukungan & Negatif & 60 & $52,6 \%$ \\
Keluarga & Positif & 54 & $47,4 \%$ \\
& Tidak ada & & \\
& dukungan & 69 & $60,5 \%$ \\
& Ada dukungan & 45 & $39,5 \%$ \\
\hline
\end{tabular}

Hasil analisis perilaku menunjukan bahwa dari 114 responden yang tidak melakukan pencegahan kehamilan di usia dini sebesar 67 responden $(58,8 \%)$ dan yang melakukan pencegahan kehamilan di usia dini sebesar 47 responden $(41,2 \%)$.

Berdasarkan hasil penelitian dari pengkategorian pengetahuan terhadap perilaku pencegahan kehamilan di usia dini pada remaja putri, dari 114 responden yang pengetahuannya rendah sebanyak 73 responden $(64,0 \%)$ sedangkan yang pengetahuannya tinggi sebanyak 41 responden $(36,0 \%)$.

Berdasarkan hasil penelitian dari pengkategorian sikap terhadap perilaku pencegahan kehamilan di usia dini pada remaja putri, dari 114 responden yang sikapnya negatif sebanyak 60 responden $(52,6$ $\%$ ) sedangkan yang sikapnya positif sebanyak 54 responden $(47,4 \%)$.
Berdasarkan hasil penelitian dari pengkategorian dukungan keluarga terhadap perilaku pencegahan kehamilan di usia dini pada remaja putri, dari 114 responden yang dukungan keluarganya tidak ada dukungan sebanyak 69 responden $(60,5 \%)$ sedangkan yang ada dukungan sebanyak 45 responden $(39,5 \%)$.

Hasil dari uji Kai Kuadrat diperoleh remaja putri yang mempunyai perilaku pencegahan kehamilan di usia dini yang tidak melakukan pencegahan pada pengetahuan rendah sebanyak $51 \quad(69,9 \%)$, sementara remaja putri yang melakukan pencegahan kehamilan di usia dini pada pengetahuan tinggi sebanyak $25(61,0 \%)$. Hasil uji statistik di peroleh nilai p-value adalah $0,003<\alpha$ $(0,05)$, sehingga dapat dinyatakan bahwa ada hubungan antara pengetahuan dengan perilaku pencegahan kehamilan di usia dini. Hasil analisis lebih lanjut didapatkan $\mathrm{OR}=3,622$ remaja putri dengan pengetahuan tinggi mempunyai peluang 3,622 kali untuk berperilaku melakukan pencegahan kehamilan di usia dini dibanding remaja putri dengan pengetahuan rendah (Tabel 2).

Hasil dari uji Kai Kuadrat diperoleh remaja putri yang mempunyai perilaku pencegahan kehamilan di usia dini yang tidak melakukan pencegahan pada sikap negatif sebanyak $52(86,7 \%)$, sementara remaja putri yang melakukan pencegahan kehamilan di usia dini pada sikap positif sebanyak 39 $(72,2 \%)$. Hasil uji statistik di peroleh nilai pvalue adalah $0,000<\alpha(0,05)$, sehingga dapat dinyatakan bahwa ada hubungan antara sikap dengan perilaku pencegahan kehamilan di usia dini. Hasil analisis lebih lanjut didapatkan $\mathrm{OR}=16,900$ remaja putri dengan sikap positif mempunyai peluang 16,900 kali untuk berperilaku melakukan pencegahan kehamilan di usia dini dibanding remaja putri dengan sikap negatif.

Hasil dari uji Kai Kuadrat diperoleh remaja putri yang mempunyai perilaku pencegahan kehamilan di usia dini yang tidak melakukan pencegahan pada yang tidak ada dukungan dari keluarga sebanyak 48 (69,6\%), sementara remaja putri yang melakukan pencegahan kehamilan di usia dini pada 
Tabel 2. Hasil Analisis Bivariat

\begin{tabular}{|c|c|c|c|c|c|c|c|}
\hline \multirow{3}{*}{ Variabel } & \multirow{3}{*}{ Kategori } & \multicolumn{4}{|c|}{ Perilaku pencegahan kehamilan usia dini } & \multirow{3}{*}{$\mathbf{P v}$} & \multirow{3}{*}{ OR } \\
\hline & & \multicolumn{2}{|c|}{ Tidak Melakukan } & \multicolumn{2}{|c|}{ Melakukan } & & \\
\hline & & $\mathbf{n}$ & $\%$ & $\mathbf{n}$ & $\%$ & & \\
\hline \multirow{2}{*}{ Pengetahuan } & Rendah & 51 & 69,9 & 22 & 30,1 & 0,003 & 3,622 \\
\hline & Tinggi & 16 & 39,0 & 25 & 61,0 & & \\
\hline \multirow[t]{2}{*}{ Sikap } & Negatif & 52 & 86,7 & 8 & 13,3 & 0,000 & 16,900 \\
\hline & Positif & 15 & 27,8 & 39 & 72,2 & & \\
\hline \multirow[t]{2}{*}{ Dukungan keluarga } & Tidak ada & 48 & 69,6 & 21 & 30,4 & 0,007 & 32,128 \\
\hline & Ada & 19 & 42,2 & 26 & 57,8 & & \\
\hline
\end{tabular}

dukungan keluarga yang ada dukungan dari keluarga sebanyak 26 (57,8\%). Hasil uji statistik di peroleh nilai p-value adalah 0,007 $<\alpha(0,05)$, sehingga dapat dinyatakan bahwa ada hubungan antara dukungan keluarga dengan perilaku pencegahan kehamilan di usia dini. Hasil analisis lebih lanjut didapatkan $\mathrm{OR}=3,128$ remaja putri dengan dukungan keluarga yang ada dukungan mempunyai peluang 3,128 kali untuk berperilaku melakukan pencegahan kehamilan di usia dini dibanding remaja putri yang tidak ada dukungan dari keluarga.

\section{PEMBAHASAN}

\section{Pengetahuan Dengan Perilaku Pencegahan Kehamilan Usia Dini}

Dari hasil penelitian ini, diketahui 41 remaja dengan pengetahuan tinggi yang melakukan pencegahan atau penolakan kehamilan usia dini adalah sebesar 25 $(61,0 \%)$ remaja putri dan dari 73 remaja putri dengan pengetahuan rendah yang melakukan pencegahan atau penolakan kehamilan usia dini adalah sebesar $22(30,1 \%)$ remaja putri. Dan berdasarkan hasil uji statistik didapat $\mathrm{p}$ value $(p=0,003)$, bahwa ada hubungan antara pengetahuan dengan perilaku pencegahan kehamilan usia dini. Hasil analisis lebih lanjut didapatkan OR $=3,622$ artinya remaja putri dengan pengetahuan tinggi mempunyai peluang 3,622 kali untuk berperilaku melakukan pencegahan kehamilan di usia dini dibanding remaja putri dengan pengetahuan rendah. Berdasarkan hasil penelitian tersebut dapat dinyatakan bahwa semakin tinggi pengetahuan remaja tentang pencegahan kehamilan di usia dini, maka perilaku pencegahan kehamilan di usia dini pada remaja putri semakin baik. Apabila pengetahuan remaja putri rendah tentang pencegahan kehamilan di usia dini, maka perilaku pencegahan kehamilan di usia dini pada remaja putri semakin buruk.

Hal ini sejalan dengan penelitian yang dilakukan oleh Endarto yang berjudul "Hubungan Tingkat Pengetahuan Tentang Kesehatan Reproduksi Dengan Perilaku Seksual Berisiko pada Remaja di SMK Negeri 4 Yogyakarta”, dengan p-value 0,008 $(p<0.05)$, sehingga H0 ditolak dengan demikian ada hubungan antara pengetahuan kesehatan reproduksi dengan perilaku seksual beresiko pada remaja. ${ }^{9}$ Hal ini juga sesuai dengan penelitian yang dilakukan oleh Ririn Darmasih yang menunjukan bahwa p-value $0,000(\mathrm{p}<0,04)$ dengan demikian ada hubungan antara pengetahuan dengan perilaku seks pranikah. ${ }^{10}$

Hasil penelitian ini sejalan dengan pernyataan Selamiharja \& Yudana $^{11}$ Informasi yang salah tentang seks dapat mengakibatkan pengetahuan dan persepsi seseorang mengenai seluk-beluk seks itu sendiri menjadi salah. Hal ini menjadi salah satu indikator meningkatnya perilaku seks bebas di kalangan remaja saat ini. Pengetahuan yang setengah-setengah justru lebih berbahaya dibandingkan tidak tahu sama sekali, kendati dalam hal ini ketidaktahuan bukan berarti tidak berbahaya. Informasi yang tepat akan membantu remaja dalam mengambil keputusan yang tepat mengenai segala hal yang berhubungan dengan kesehatan reproduksinya sehingga mereka dapat melindungi diri dari kehamilan di usia dini, aborsi tidak aman, infeksi menular seksual, dan sebagainya. Pengetahuan tentang kesehatan reproduksi yang kurang ditambah dengan dorongan seksual yang kuat pada usia 
remaja maka mereka cenderung menggali pengetahuan lebih jauh dengan cara mencobacoba. Pemberian informasi tentang kesehatan reproduksi yang benar dan sesuai dengan perkembangan fisik dan psikologis anak akan berdampak positif pada perilaku remaja. Bekal pengetahuan yang cukup membuat remaja lebih bertanggung jawab dalam berperilaku dan lebih mampu melindungi diri remaja dari berbagai gangguan kesehatan reproduksi dan terhindar dari kehamilan di usia dini. Menurut pernyataan Wildan $^{12}$ bahwa pengetahuan seksualitas adalah pengetahuan yang menyangkut cara seseorang bersikap atau bertingkah laku yang sehat, bertanggung jawab serta tahu apa yang dilakukan dan apa akibat bagi dirinya, pasangannya dan masyarakat sehingga dapat membahagiakan dirinya dan juga dapat memenuhi kehidupan seksualnya. Menurut Mubarak $^{13}$ Pengetahuan merupakan hasil mengingat suatu hal, termasuk mengingat kembali kejadian yang pernah dialami baik secara sengaja maupun tidak disegaja dan ini terjadi setelah orang melakukan kontak atau pengamatan terhadap suatu objek tertentu. Perilaku yang didasar oleh pengetahuan akan lebih langgeng atau lebih baik dari pada perilaku yang tidak didasari oleh pengetahuan.

Namun penelitian ini bertentangan dengan penelitian yang dilakukan Sugianty ${ }^{14}$ yang menyatakan bahwa tidak ada hubungan yang bermakna antara pengetahuan dengan perilaku seksual remaja dengan nilai $p$-value $0,887(\mathrm{p}>0,05)$. Penelitian ini sejalan dengan penelitian Nisa Nurkhotimah ${ }^{15}$ yang menyatakan bahwa tidak ada hubungan antara pengetahuan dengan perilaku seksual berisiko dengan nilai $p$-value $1,00(\mathrm{p}>0,05)$.

Hasil penelitian ini sejalan dengan pernyataan Green (1980) ${ }^{14}$ yang menyatakan bahwa peningkatan pengetahuan tidak selalu menyebabkan perubahan perilaku. Pengetahuan tentang kesehatan penting sebelum sesuatu tindakan kesehatan yang diharapkan terjadi, akan tetapi tindakan kesehatan yang diharapkan mungkin tidak akan terjadi kecuali apabila seseorang mendapatkan isyarat yang cukup kuat untuk memotivasinya. Perilaku seksual remaja tidak hanya ditentukan oleh tingkat pengetahuan seksualnya akan tetapi lebih ditentukan oleh kematangan psikososialnya sehingga remaja dapat menentukan yang terbaik bagi dirinya serta tidak mudah terpengaruh oleh lingkungannya. Dalam hal ini seseorang yang berpengetahuan baik akan tetapi tidak didukung oleh minat, keinginan, kehendak ataupun motivasi yang baik, perilakunya bisa saja menjadi tidak baik. Begitu pula dengan seseorang yang berpengetahuan yang kurang, bisa saja mereka mempunyai kehendak dan motivasi yang baik sehingga perilakunya bisa saja menjadi baik.

Kurangnya pengetahuan tentang kehamilan usia dini dengan demikian wanita kurang mengerti tentang resiko yang akan terjadi akibat dari kehamilan di usia dini dan apabila berpengatahuan baik maka sedikit tidaknya wanita mengerti tentang resiko yang akan timbul apabila hamil di usia dini. Oleh karena itu pengetahuan sangat berpengaruh terhadap kehamilan di usia dini.

Pengetahuan tentang pencegahan kehamilan usia dini bukanlah pengetahuan yang hanya sembarangan dibicarakan sekilas saja sebab membutuhkan pengetahuan dengan system pendidikan yang lebih menjurus kepada arah materi pencegahan kehamilan usia dini tersebut. Lingkungan sekolah dipandang sebagai tempat anak belajar bersosialisasi, dan memperoleh pendidikan dan ketrampilan untuk dapat hidup dengan baik di masyarakat. Cara untuk meningkatkan pengetahuan remaja dengan memberikan penyuluhan tentang kesehatan reproduksi, pendidikan seks serta dampak dari kehamilan diusia dini, kemudian diadakannya evaluasi kepada remaja apakah mereka mengerti dengan penyuluhan yang diberikan pihak sekolah.

\section{Sikap Dengan Perilaku Pencegahan Kehamilan Usia Dini}

Dari hasil penelitian ini, di dapat dari 54 remaja putri yang memberikan sikap positif terhadap perilaku pencegahan kehamilan usia dini, yang melakukan pencegahan atau penolakan kehamilan usia dini adalah sebesar 
$39(72,2 \%)$ remaja putri dan dari 60 remaja putri yang memberikan sikap negatif terhadap perilaku pencegahan kehamilan usia dini, yang melakukan pencegahan atau penolakan kehamilan usia dini adalah sebesar $8(13,3 \%)$ remaja putri. Berdasarkan hasil uji statistik di dapat $\mathrm{p}$-value $(\mathrm{p}=0,000)$, bahwa ada hubungan antara sikap dengan perilaku pencegahan kehamilan usia dini. Hasil analisis lebih lanjut didapatkan $\mathrm{OR}=16,900$ remaja putri dengan sikap positif mempunyai peluang 16,900 kali untuk berperilaku melakukan pencegahan kehamilan di usia dini dibanding remaja putri dengan sikap negatif. Berdasarkan hasil penelitian tersebut dapat dinyatakan bahwa semakin baik sikap remaja tentang pencegahan kehamilan di usia dini, maka perilaku pencegahan kehamilan di usia dini pada remaja putri semakin baik. Dan apabila sikap remaja putri buruk terhadap pencegahan kehamilan di usia dini, maka perilaku pencegahan kehamilan di usia dini pada remaja putri semakin buruk.

Hal ini sejalan dengan penelitian yang dilakukan oleh Yeni Rosyeni dan Isti Dariah yang berjudul "Hubungan Pengetahuan Dan Sikap Remaja Putri Terhadap Kehamilan Remaja Di Puskesmas Cipageran Cimahi Utara Tahun 2010", dengan $p$-value 0,033 ( $p$ $<0.05$ ), sehingga $\mathrm{H} 0$ ditolak dengan demikian ada hubungan antara sikap dengan kehamilan remaja. ${ }^{16}$ Hasil penelitian ini didukung oleh penelitian yang dilakukan oleh Sugianty yang menunjukan bahwa ada hubungan antara sikap dengan perilaku seksual remaja degan nilai $p$-value $0,011(\mathrm{p}<0,05) .{ }^{14}$

Sikap merupakan predisposisi terjadinya perilaku atau reaksi tertutup dan belum merupakan perilaku atau reaksi terbuka. ${ }^{17}$ Sikap merupakan potensi tingkah laku seseorang terhadap sesuatu keinginan yang dilakukan. Maka dapat dikatakan seorang remaja yang bersikap kurang baik terhadap seksualitas cenderung akan mengarah ke perilaku seksual negatif. Hal ini dikarenakan kurangnya informasi, pengetahuan remaja dan pemahaman yang baik mengenai kesehatan reproduksi dan seksualitas yang benar. ${ }^{18}$ Hal tersebut sesuai dengan teori Newcomb, bahwa sikap merupakan kesiapan atau kesediaan untuk bertindak, dan bukan merupakan pelaksanaan motif tertentu, sehingga sikap belum tentu terwujud dalam tindakan. ${ }^{17}$

Namun penelitian ini bertentangan dengan penelitian yang dilakukan I Nyoman Gede Sanjaya yang menyatakan bahwa tidak ada hubungan yang bermakna antara sikap dengan perilaku seksual remaja dengan nilai p-value $0,131(\mathrm{p}>0,05) .{ }^{19}$

Menurut Newcomb (1978) $)^{5}$ sikap merupakan suatu kesediaan untuk bertindak, belum merupakan suatu tindakan atau aktivitas, tetapi merupakamn predisposisi tingkah laku. Predisposisi ini mencakup komponen kognisi, afeksi, dan konasi. Komponen kognisi berhubungan dengan keyakinan, ide dan konsep, yang akan menjawab pertanyaan tentang apa yang di pikirkan atau di persepsikan. Komponen afeksi menyangkut kehidupan emosional, yang menjawab pertanyaan tentang bertingkah laku, yang menjawab pertanyaan bagaimana kesediaan atau kesiapan untuk bertindak. Dari pernyataan tersebut menunjukan bahwa sikap merupakan faktor predisposisi yang mencakup komponen kognisi, afeksi, dan konasi yang merupakan gabungan dari hubungan ide, keyakinan, konsep, kehidupan emosional dan kecenderungan bertingkah laku yang terkait dengan kesiapan untuk bertindak. Sehingga dapat disimpulkan bahwa sikap yang positif belum tentu tidak akan berperilaku seksual beresiko dan sikap yang negatif juga belum tentu pasti melakukan perilaku seksual yang beresiko.

Semakin baik seorang remaja dalam merespon suatu objek tertentu, maka semakin baik pula remaja tersebut bersikap. Sikap positif ditunjukkan dengan mampu melakukan penanganan dini dan pencegahan dini terhadap kehamilan di usia remaja. Upaya yang dapat dilakukan untuk peningkatan perilaku yang positif adalah membentuk sikap yang diwujudkan melalui pemberdayaan guru, orangtua, seta tenaga kesehatan untuk memberikan pemahaman mengenai pencegahan resiko kehamilan diusia dini serta dampak yang diakibatkan dari 
kehamilan diusia dini kepada remaja sehingga akhirnya memunculkan sikap positif dan perilaku positif yaitu melakukan pencegahan terhadap resiko kehamilan di usia dini oleh remaja dan remaja juga akan lebih bertanggung jawab terhadap diri dan kesehatannya.

\section{Dukungan Keluarga Dengan Perilaku Pencegahan Kehamilan Usia Dini}

Dari hasil penelitian ini, diketahui 45 remaja ada dukungan dari keluarga yang melakukan pencegahan atau penolakan kehamilan usia dini adalah sebesar 26 $(57,8 \%)$ remaja putri, dan dari 69 remaja putri tidak ada dukungan dari keluarga terhadap perilaku pencegahan kehamilan usia dini, yang melakukan pencegahan atau penolakan kehamilan usia dini adalah sebesar 21 $(30,4 \%)$ remaja putri. Berdasarkan hasil uji statistik di dapat $\mathrm{p}$-value $(\mathrm{p}=0,007)$, bahwa ada hubungan antara dukungan keluarga dengan perilaku pencegahan kehamilan usia dini. Hasil analisis lebih lanjut didapatkan OR $=3,128$ remaja putri dengan dukungan keluarga yang ada dukungan mempunyai peluang 3,128 kali untuk berperilaku melakukan pencegahan kehamilan di usia dini dibanding remaja putri yang tidak ada dukungan dari keluarga. Berdasarkan hasil penelitian tersebut dapat dinyatakan bahwa semakin baik dukungan keluarga pada remaja terhadap pencegahan kehamilan di usia dini, maka perilaku kehamilan diusia dini pada remaja semakin baik. Dan apabila semakin buruk dukungan keluarga pada remaja putri tentang pencegahan kehamilan di usia dini, maka perilaku pencegahan kehamilan di usia dini pada remaja semakin buruk.

Hal ini sejalan dengan penelitian yang dilakukan oleh Mambang dkk yang berjudul "Hubungan Peran Orang Tua Terhadap Perilaku Remaja Dalam Mencegah Terjadinya Resiko Kehamilan Di Usia Dini Pada Siswi SMA Swasta X Banjarmasin", dengan $p$ value $0,000(p<0.05)$, sehingga $\mathrm{H} 0$ ditolak dengan demikian ada hubungan antara peran orang tuan dengan perilaku remaja dalam mencegah terjadinya kehamilan di usia dini. ${ }^{20}$ Hasil penelitian ini didukung oleh penelitian yang dilakukan oleh Ririn darmasih yang menunjukan bahwa ada hubungan antara dukungan keluarga dengan perilaku seks pra nikah, dengan nilai $\mathrm{p}$-value $0,000(\mathrm{p}<0,05) .{ }^{10}$

Hal ini sejalan dengan teori oleh Widyastuti menyatakan adanya perhatian atau kontrol orang tua terhadap anak dapat menunda usia pertama kali remaja melakukan hubungan seks. ${ }^{21}$ Hasil penelitian ini mendukung pendapat Laily dan Matulessy kualitas komunikasi antara orangtua dan anak dapat menghindarkan remaja dari perilaku seksual pranikah, hal ini dikarenakan antara orangtua dan anak terjalin hubungan atau komunikasi yang intensif sehingga memungkinkan terjadinya diskusi, sharing, dan pemecahan masalah secara bersama. ${ }^{22}$ Komunikasi dalam keluarga adalah jembatan interaksi antara oran tua dengan anaknya, tetapi bukan merupakan magic carpet yang dapat menyelesaikan segala masalah. Hal ini merupakan penjelasan bahwa tidak benar selalu menjadikan komunikasi yang buruk dalam keluarga sebagai satu-satunya penyebab kenakalan remaja, ketidakharmonisan keluarga dan sebagainya. Masih banyak hal lain yang saling terkait seperti saling pengertian dari kedua belah pihak, saling menghargai dan menghormati, keterusterangan ataupun adanya rasa empati. Komunikasi orang tua-anak dikatakan efektif apabila kedua belah pihak saling dekat, saling menyukai dan komunikasi diantaranya merupakan hal yang menyenangkan dan adanya keterbukaan sehingga tumbuh sikap percaya. Hal ini sejalan juga dengan pendapat yang menyatakan orang tua merupakan orang pertama yang memberikan dasar pembentukan tingkah laku, watak, moral dan pendidikan kepada anak. ${ }^{23}$

Namun penelitian ini bertentangan dengan penelitian yang menunjukan bahwa tidak ada hubungan antara sikap dengan perilaku seksual remaja dengan nilai $p$-value $0,195$ ( $p>0,05) .{ }^{14}$ Hasil penelitian ini selaras oleh penelitian yang dilakukan I Nyoman Gede Sanjaya yang menunjukan bahwa tidak ada hubungan antara komunikasi orang tua dengan perilaku seksual remaja dengan nilai p-value $0,765(\mathrm{p}>0,05){ }^{19}$ 
Kebanyakan orang tua memang masih menganggap tabu untuk membicarakan masalah seksualitas dengan anaknya. Padahal lingkungan keluarga merupakan tempat yang tepat dan baik untuk penyuluhan masalah seks. Sampai sekarang, kesempatan ini jarang digunakan oleh orang tua, karena masalah seks disampingkan atau ditutupi. Hal ini mugkin saja disebabkan oleh orang tua yang tidak memiliki info yang banyak dan benar tentang seksualitas, serta tidak tahu cara yang tepat untuk menyampaikannya kepada anak remajanya, disamping itu menjadi orang tua bagi remaja masa kini dirasakan lebih sulit dari pada beberapa puluh tahun yang lalu. Adanya perubahan-perubahan sosiologis dan teknologis yang begitu pesat ternyata membawa dampak pada perubahan dalam hubungan anak dan orang tua.

Semakin baik hubungan keluarga seorang remaja, maka semakin baik pula remaja itu berperilaku. Hal ini didasari bahwa dukungan keluarga atau peran orang tua berpengaruh besar terhadap pengetahuan anak dalam membentuk kepribadiannya dengan cara mengarahkan, membimbing dan memperhatikan masalah-masalah emosional, Anak-anak perlu mengerti bahwa mereka bisa bicara dengan kita dan kita dapat membantu mereka menghadapi situasi tersebut dan memberikan pemahaman bahwa kehamilan di usia dini adalah sesuatu yang tidak dapat diterima. Sebagai orangtua, kita perlu mendidik anak secara baik agar tumbuh menjadi aktif, cerdas, dan memiliki masa depan cemerlang.

\section{KESIMPULAN}

Dari penelitian tersebut dapat disimpulkan bahwa variabel perilaku pencegahan kehamilan di usia dini dapat dipengaruhi oleh variabel pengetahuan, sikap, dan dukungan keluarga. Variabel tersebut sangat mempengaruhi pola pikir dan tingkah laku remaja putri terhadap resiko kehamilan di usia dini, sehingga untuk menurunkan perilaku resiko kehamilan di usia dini diperlukan tingkat pengetahuan yang baik yang dapat memberi pengetahuan tentang perilaku pencegahan kehamilan usia dini, sehingga remaja putri akan lebih dapat bertanggung jawab terhadap dirinya dan kesehatannya, karena jika perilakunya buruk dan tidak dirubah akan terbawa sampai usia dewasa justru akan merugikan masa depan remaja itu sendiri.

\section{DAFTAR PUSTAKA}

1. Holisah L. Pendidikan Terbaik Melahirkan Generasi Terbaik, at : http://m.kompasiana.com/post/read/634611/1 /pendidikan-terbaik-melahirkan generasiterbaik.html.Diakes 26 februari 2014

2. Santrock JW. Adolescence, Perkembangan Remaja, Jakarta : Erlangga ; 2010.

3. Susana A, Epidemiologi Kontemprorer Terhadap Remaja, at http://susanaasgun.blogspot.com, 2014

4. Banun FOS, dan Setyorogo S. Faktor-Faktor Yang Berhubungan Dengan Perilaku Seksual Pranikah Pada Mahasiswa Semester V STIKES X Jakarta Timur, 2012.

5. Sekarrini L. Skripsi Faktor-Faktor Yang Berhubungan Dengan Perilaku Seksual Remaja Di SMK Kesehatan Di Kabupaten Bogor Tahun 2013; UI Depok.

6. Kusmiran. Kesehatan Reproduksi Remaja Dan Wanita. Jakarta: Salemba Medika; 2011.

7. Irianto K. Memahami Seksiologi Remaja, Bandung: Sinar Baru Algesindo; 2010.

8. Suraji, Rahmawatie S. Pendidikan Seks Bagi Anak. Yogyakarta: Pustaka Fahma; 2008.

9. Yulian E, Parmadi SP. Hubungan Tingkat Pengetahuan Tentang Kesehatan Reproduksi Dengan Perilaku Berisiko Pada Remaja Di SMK Negeri 4 Yogyakarta, Jurnal; https://skripsistikes.files.wordpress.com/2009 /08/12.pdf

10. Ririn D. Faktor Yang Mempengaruhi Perilaku Seks Pranikah Pada Remaja Di Srakarta, Skripsi http://publikasiilmiah.ums.ac.id/bitstream/ha ndle/123456789/2940/1.\%20RIRIN.pdf?sequ ence $=1$

11. Martina E, Dewi ES. Jurnal Hubungan Antara Persepsi Tentang Seks Dan Perilaku Seksual Remaja Di SMA Negeri 3 Medan 2009, at : http://repository.usu.ac.id

12. Amrillah A, A Prasetyoningrum, Hertinjung WS. Hubungan Antara Pengetahuan Seksualitas Dan Kualitas Komunikasi Orang Tua-Anak Dengan Perilaku Seksual Pranikah, Indigenous, Jurnal Ilmiah; 2009. 
13. Mubarak, Wahit I, dkk, Promosi Kesehatan Sebuah Pengantar Dan Proses Belajar Mengajar Dalam Pendidikan, Yogyakarta : Graha Ilmu; 2007.

14. Sugianty. Pengetahuan, Keyakinan Dan Sikap Terhadap Perilaku Seksual Remaja Pada Siswa SMK Putra Bangsa Kota Depok, Skripsi FKM UI Depok ; 2003.

15. Nisa N. Faktor-Faktor Yang Mempengaruhi Perilaku Seksual Pranikah Remaja Kelas XI SMA Budhi Warman II Jakarta, Skripsi UI Depok ; 2013.

16. Yeni R, Isti D. Hubungan Pengetahuan Dan Sikap Remaja Putri Dengan Kehamilan Remaja Di Puskesmas Cipageran Cimahi Utara Tahun 2010, Jurnal; http://stikesayani.ac.id/publikasi/ejournal/files/2011/201108/201108-005.pdf

17. Notoatmodjo S. Metodologi Penelitian Kesehatan. Jakarta: Rineka Cipta; 2010.

18. Sarwono SW. Psikologi Remaja, Jakarta: PT. Raja Gravido Persada; 2003.

19. Marseliana. Skripsi Hubungan Pola Komunikasi Remaja 14-17 Tahun Dalam Keluarga Dengan Perkembangan Sosial Remaja Di SMK Mandiri Bojong Gede Bogor 2011, at : http://id.scribd.com/doc/91911271/SKRIPSIPola-Komunikasi-Orangtua\#scribd

20. Mambang, Anggrita S, Ika H. Hubungan Pengetahuan Dengan Peran Orang Tua Dalam Mencegah Terjadinya Resiko Kehamilan Di Usia Remaja Pada Siswa SMA Swasta X Banjarmasin, Jurnal ; http://akbidsarimulya.ac.id.

21. Widyastuti $\mathrm{Y}, \mathrm{dkk}$, Kesehatan Reproduksi, Yogyakarta: Pitramaya; 2009.

22. Riska K, Heni SER, Mahmudah. Hubungan Antara Komunikasi Orang Tua-Anak Remaja Tentang Kesehatan Reproduksi Dengan Perilaku Seks Pranikah Di SMA Negeri I Salaman Kbupaten Magelang,at: http://jurnal.unimus.ac.id

23. Soetjiningsih. Tumbuh Kembang Remaja dan Permasalahannya, Jakarta: Sagung Seto; 2007. 